\title{
PENGARUH AIR REBUSAN BUAH MAHKOTA DEWA TERHADAP PENURUNAN GULA DARAH PADA PASIEN DIIABETES MELITUS TIPE II
}

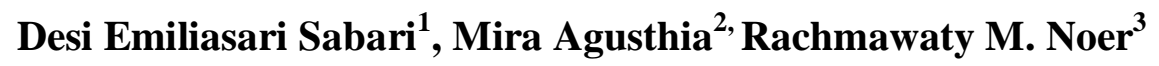 \\ Program Studi Ilmu Keperawatan, STIKes Awal Bros Batam \\ Email : agusthiamira@gmail.com
}

\begin{abstract}
ABSTRAK
Penggunaan tanaman mahkota dewa merupakan alternatif untuk mencegah efek radikal bebas pada DM. Selain itu dikenal juga beberapa obat anti diabetes seperti brotowali, mimba, daun salam dan lain-lain. Mahkota dewa sebagai obat asli indonesia banyak digunakan untuk berbagai penyakit diantaranya sebagai anti diabetes. Tujuan dari penelitian ini adalah untuk mengetahui pengaruh air rebusan buah mahkota dewa terhadap penurunan gula darah pasien diabetes melitus tipe II di Puskesmas Dabo Lama Kabupaten Lingga Penelitian. Rancangan penelitian ini adalah penelitian kuantitatif dengan metode pengambilan sampel ini adalah purposive sample. Sampel dalam penelitian ini terdiri dari 18 orang dan data dianalisis menggunakan uji paired t-test. Hasil diketahui sebesar 88,9\% sampel memiliki perbedaan kadar gula darah sebelum dan sesudah pemberian air rebusan mahkota dewa, dan $11.1 \%$ tidak memiliki perbedaan sebelum dan sesudah diberikan air rebusan makota dewa. Kesimpulan dari analisa data diketahui $\mathrm{p}$-value bernilai $0,000(\mathrm{p}=<0,05)$, menunjukkan ada pengaruh air rebusan mahkota dewa terhadap penurunan gula darah pada pasien diabetes mellitus tipe II di Puskesmas Dabo Lama Kabupaten Lingga. Adanya pengaruh air rebusan buah mahkota dewa terhadap penurunan kadar gula darah dapat digunakan sebagai salah satu pengobatan alternatif non farmakologi.
\end{abstract}

Kata Kunci : Diabetes Melitus, Mahkota Dewa 


\begin{abstract}
The use of the god's crown plant is an alternative to prevent the effects of free radicals in DM. In addition, there are also several anti-diabetes drugs such as brotowali, neem, bay leaves and others. Mahkota Dewa as a native Indonesian medicine is widely used for various diseases including as anti-diabetes.. The purpose of this study was to determine the effect of boiled water from the Phaleria Macrocarpa on reducing blood sugar in patients with type II diabetes mellitus at the Dabo Lama Community Health Center, Lingga Regency. The design of this study is quantitative research with this sampling method is purposive sample. The sample in this study consisted of 18 people and the data were analyzed using paired t-test. The recognized results of $88.9 \%$ of the sample had blood sugar levels before and given Phaleria Macrocarpa boiled water, and $11.1 \%$ had no difference before and were given Phaleria macrocarpa boiled water. The conclusion from the analysis of data that is recognized as $p$-value of $0,000(p=<0.05)$, shows that there is an influence of Phaleria macrocarpa on blood sugar in type II diabetes mellitus patients in Dabo Lama Health Center, Lingga Regency. The effect of boiled water from Phaleria Macrocarpa on reducing blood sugar levels can be used as a nonpharmacological alternative medicine.
\end{abstract}

Keywords: $\quad$ Diabetes Mellitus, Phaleria Macrocarpa 


\section{PENDAHULUAN}

Penyakit diabetes mellitus atau lebih dikenal di masyarakat sebagai kencing manis merupakan suatu kelompok penyakit metabolik dengan karateristik hiperglikemia yang terjadi karena kelainan sekresi insulin, kerja insulin atau keduaduanya (Soelistijo et al., 2015).

Berdasarkan data dari Dinas Kesehatan Kabupaten Lingga tercatat pada 2018 lalu, sebanyak 2769 kasus dan pada tahun 2019 dari bulan Januari sampai dengan Oktober Puskesmas Dabo Lama adalah 419 kasus . "Tingginya prevalensi diabetes mellitus dapat disebabkan oleh banyak faktor, diantaranya adalah faktor keturunan atau genetik, kegemukan atau obesitas, usia lanjut, jenis kelamin, perubahan gaya hidup, pola makan yang salah, resistensi insulin, obat-obatan yang mempengaruhi kadar glukosa darah, kurangnya aktifitas fisik, kehamilan, perokok, konsumsi alkohol dan ketegangan atau stress" (Muflihatin, 2015).

Penatalaksanaan diabetes mellitus dibagi dua, nonfarmakologis dan farmakologis, yaitu dengan obat-obatan penurun kadar gula darah (KGD), seperti insulin dan obat anti diabetik oral (Soelistijo et al., 2015). Secara nonfarmakologis salah satunya dengan memberikan air rebusan mahkota dewa, yang mengandung kandungan kimia. Adapun kandungan kimia buah mahkota dewa terdiri dari flavonoid, alkaloid dan polifenol.

Kandungan buah mahkota dewa antara lain berisi "alkaliod, flavonoid (terutama quercetin yang berfungsi mempunyai sifat anti- oksidan), saponin (mengurangi kadar gula darah), folifenol (bersifat anti oksidan), terpenoid dan tanin. Penggunaan tanaman mahkota dewa merupakan alternatif untuk mencegah efek radikal bebas pada DM". Selain itu dikenal juga beberapa obat anti diabetes seperti brotowali, mimba, daun salam dan lainlain. Mahkota dewa sebagai obat asli indonesia banyak digunakan untuk berbagai penyakit diantaranya sebagai anti diabetes.

"Tujuan dari penelitian ini adalah untuk mengetahui pengaruh air rebusan buah mahkota dewa terhadap penurunan gula darah pasien diabetes melitus tipe II di Puskesmas Dabo Lama Kabupaten Lingga". Mahkota dewa (Phaleria macrocarpa) merupakan "tanaman obat yang sudah dikenal dan saat ini diminati masyarakat. Tanaman yang berasal dari Papua berkhasiat untuk mengobati luka, diabetes, liver, flu, alergi, sesak napas, penyakit kulit, jantung dan darah tinggi" (Rohyami, 2011). 
"Pengaruh Saponin dalam buah mahkota dewa terhadap penurunan kadar gula darah diteliti oleh Nuzulut Fiana, Dwita Oktara, Falkutas Kedokteran Universitas

\section{METODE PENELITIAN}

Desain penelitian yang digunakan pada penelitian ini adalah "quasi eksperimen dan penelitian ini dilakukan untuk mengetahui Pengaruh air Rebusan Buah Mahkota Dewa Terhadap Kadar gula darah pada pasien Diabetes Melitus tipe 2 di Puskesmas Dabo Lama Kabupaten Lingga. Jumlah sampel dalam penelitian ini adalah 18 sampel. Dalam penelitian ini, terdapat dua kriteria yaitu inklusi dan eksklusi. Kriteria inklusi yakni Responden penyakit diabetes mellitus tipe II yang berada di wilayah kerja Puskesmas Dabo lama, responden yang bersedia menjadi responden dan mengikuti prosedur penelitian, Responden yang mempunyai

\section{HASIL DAN PEMBAHASAN}

Berdasarkan Distribusi Frekuensi Usia, Jenis kelamin, Lamanya Diabetes Melitus Type II, BMI, pasien Diabetes Melitus di Puskesmas Dabo lama Kabupaten Lingga dapat di lihat pada ringkasan di bawah ini :

a. Usia

Berdasarkan distribusi yang didapatkan pada kelompok Intervensi dengan jumlah responden sebanyak 18 orang
Lampung (2016)”. Tujuan penelitian "untuk mengetahui pengaruh buah mahkota dewa terhadap penurunan kadar gula darah".

riwayat DM Tipe II. Kriteria eksklusi yakni, responden yang tidak bersedia menjadi responden dan mengikuti prosedur penelitian, Responden yang tidak mempunyai riwayat DM Tipe II, "apabila bila $\rho$ value (nilai signifikan) $\leq \alpha(0,05)$ maka Ho gagal ditolak, artinya bahwa ada pengaruh pemberian air rebusan buah mahkota dewa terhadap kadar gula darah pada pasien Diabetes mellitus tipe 2 . Apabila bila $\rho$ value (nilai signifikan) $\geq \alpha$ $(0,05)$ maka Ha diterima, artinya bahwa tidak ada pengaruh pemberian air rebusan buah mahkota dewa terhadap kadar gula darah pada pasien diabetes mellitus tipe II".

didapat hasil sebagian besar responden berusia 45-59 tahun sebanyak 14 $(77,8 \%)$. Penelitian ini sejalan dengan penelitian yang dilakukan Dyah (2016), di Puskesmas Piyungan Bantul Yogyakarta, bahwa penderita Diabetes Melitus Tipe II berada pada usia > 50 Tahun yaitu $81,8 \%$ dikarenakan faktor resistensi insulin dan life style. Untuk 
usia diatas 61 tahun, mengalami perubahan pada tubuhnya dikarenakan terjadinya penurunan resistensi fungsi Pankreas dan sekresi insulin yang berkurang, hal ini disebabkan oleh berkurangnya masa otot dan perubahan Vaskuler sehingga golongan usia ini beresiko tinggi terkena penyakit.

Menurut Restyana (2015), "usia yang banyak terkena diabetes melitus adalah $>45$ tahun, seseorang dengan usia yang sudah tua akan mengalami kecenderungan organ-organ tubuh mulai melemah. Bahkan wanita yang sudah mengalami manopouse mempunyai kecenderungan untuk lebih tidak peka terhadap hormon insulin".

Dari hasil penelitian, analisa peneliti adalah karakteristik responden berdasarkan usia sudah sesuai dengan teori dan merupakan salah satu faktor yang mempengaruhi peningkatan kadar gula darah pada pasien. Diabetes Melitus Tipe II. Karena bertambahnya usia seseorang maka semakin tinggi kadar gula darah. Namun tidak menutup kemungkinan diderita oleh orang muda.

b. Jenis Kelamin

Berdasarkan distribusi yang didapat mayoritas responden berjenis kelamin perempuan 11 ( 61,1\%). Penelitian ini sejalan dengan penelitian Dyah ( 2011 ), dengan hasil responden penderita
Diabetes Melitus Tipe II paling banyak berjenis kelamin perempuan sebanyak 7 orang $(63,3 \%)$. Hal ini sesuai dengan pernyataan Taylor ( 2010 ) yang menyatakan bahwa "penyebab utama banyaknya perempuan terkena diabetes melitus karena terjadinya penurunan hormon estrogen terutama pada masa menopouse. Hormon esterogen dan progesteron memiliki kemampuan untuk meningkatkan respon insulin dalam darah. Saat menopouse terjadi, maka respon insulin menurun akibat hormon esterogen dan progesteron yang rendah".

Dari hasil penelitian, analisa peneliti adalah karakteristik responden berdasarkan jenis kelamin sudah sesuai dengan teori dan merupakan salah satu faktor yang mempengaruhi kadar gula darah pada pasien diabetes melitus tipe II. Karena jenis kelamin perempuan mudan terkena Obesitas dibandingkan laki-laki yang dengan aktivitas fisik.

c. Lamanya Diabetes Melitus Tpie II

Berdasarkan tabel 4.1 mayoritas responden lamanya Diabetes Melitus Tipe II yang diderita pasien selama > 5 tahun sebanyak 10 responden $(55,6 \%)$. Menurut Novindi (2018) lamanya menderita diabetes melitus hanya mempengaruhi rasio HDL dan LDL pada pasien dengan Diabetes melitus, 
hal ini dapat ditelusuri lanjut oleh peneliti selanjutnya, apakan ada hubungannya dengan kontrol glikemik yang buruk pada kelompok diabetes melitus tipe II tidak terkontrolnya atau hal ini dapat disebabkan karena lamanya menderita diabetes melitus pada kedua kelompok. Dari hasil penelitian, analisa peneliti adalah karakteristik responden berdasarkan lamanya diabetes melitus tipe II sudah sesuai dengan teori.

\section{d. Body Mass Indeks ( BMI )}

Berdasarkan tabel 4.1 mayoritas responden yang memiliki BMI sebanyak 10 responden (55.6\% ). Jika BMI normal maka kadar trigliserida menurun. Jika BMI diatas 25, pada setiap peningkatan BMI satu angka mempunyai kecenderungan menjadi kencing manis sebanyak 25\%. Jika BMI 30 atau lebih, mempunyai kecenderungan lebih besar terserang diabetes melitus, PJK, Stroke, ganggaun memori dibandingkan dengan orang yang tidak gemuk. Menurut Dyah (2011) "penderita diabetes melitus tipe II sering mempunyai kadar trigliserida yang tinggi. Banyaknya jaringan lemak membuat jaringan dalam tubuh dan otot menjadi resisten terhadap kerja insulin". "Terutama jika kelebihan berat badan lemak terkumpul didaerah perut sentral sehingga memblokir kerja insulin dan glukosa. Akhirnya tidak bisa diangkut kedalam sel dan menumpuk dalam darah” ( Maulana, 2015).

Kadar Gula Darah Sebelum Dan Sesudah Diberikan Rebusan Buah Mahkota Dewa. Air rebusan mahkota dewa dapat mengontrol kadar gula darah. Responden yang sudah diberikan air rebusan buah mahkota dewa menunjukan hasil bahwa air rebusan buah mahkota dewa dapat membantu mengontrol kadar gula darah pada pasien Diabetes Mellitus Tipe II (Rohyami, 2011).

Sebelum diberikan air rebusan mahkota dewa didapatkan hasil kadar gula darah pada pasien diabetes melitus Tipe II berada pada batas tinggi sebanyak 18 pasien ( 100 $\%$ ). Dan berdasarkan tabel 4.3 didapatkan hasil kadar gul;a darah setelah diberikan air rebusan mahkota dewa terdapat penurunan yang sangat signifikan terhadap kadar gula darah pasien yaitu sebanyak 16 pasien ( $88,9 \%$ ) dan batas tinggi sebanyak 2 pasien ( $11,1 \%$ ).

Mahkota dewa merupakan salah satu tanaman herbal yang sangat bermanfaat untuk mengobati luka, Diabetes Melitus, Liver, Flu, Penyakit jantung dan Darah tinggi ( Rohyami 2011 ). Bagian dari mahkota dewa yang digunakan dan sangat bermanfaat yaitu daging buah mahkota dewa. 
Dari hasil penelitian, analisa peneliti mengenai air rebusan buah mahkota dewa pada pasien Diabetes Melitus Tipe II mampu menurunkan kadar gula darah.

Pengaruh Air Rebusan Buah Mahkota Dewa Terhadap Penurunan Kadar Gula Darah Pada Pasien Diabetes Melitus Tipe II di Puskesmas Dabo Lama Lingga. Dari hasil uji statistik menggunakan uji Paired

\section{KESIMPULAN}

Setelah dilakukan penelitian tentang "Pengaruh Air Rebusan Buah Mahkota Dewa Terhadap Penurunan Kadar Gula Darah Pada Pasien Diabetes Mellitus Tipe II di Wilayah Jerja Puskesmas Dabo Lama Lingga 2020“, dapat ditarik kesimpulan bahwa :

1. Berdasarkan tabel 4.1 karakteristik sebagian besar pasien Diabetes Melitus Tipe II berusia 45-59 tahun sebanyak $77,8 \%$, pasien yang berjenis kelamin perempuan sebanyak $61,1 \%$, lamanya Diabetes Melitus 5-8 tahun 55,6\%, sedangkan pasien yang memiliki BMI $>25$ sebanyak $55,6 \%$.

2. Berdasarkan tabel 4.2 kadar gula darah pasien sebelum dilakukan pemberian air rebusan buah mahkota dewa sebanyak 18 pasien mengalami kadar
t-Test didapatkan hasil $\mathrm{p}$ value 0,000 $(<0,05)$, dengan demikian H0 ditolak. Dapat disimpulkan bahwa terdapat pengaruh air rebusan buah mahkota dewa terhadap penurunan kadar gula darah pada pasien Diabetes Melitus Tipe II, yang dilakukan selama 22 hari pada 18 pasien (Notoadmojo, 2010).

gula darah batas tinggi yaitu $100 \%$.

3. Berdasarkan tabel 4.3 kadar gula darah sesudah pemberian rebusan buah mahkota dewa pada 18 pasien menunjukan penurunan yang signifikan yaitu $88,9 \%$ pasien mengalami penurunan kadar gula darah.

4. Berdasarkan tabel 4.5 pengaruh air rebusan buah mahkota dewa terhadap penurunan kadar gula darah dengan hasil uji statistik yaitu menggunakan uji Paired T-Test didapatkan hasil $\mathrm{p}$ value $0,000(<0,05)$, dengan demikian H0 ditolak. Dapat disimpulkan bahwa terdapat pengaruh air rebusan buah mahkota dewa terhadap penurunan kadar gula darah pada pasien Diabetes Melitus Tipe II. 


\section{DAFTAR PUSTAKA}

Adib, M., 2011. Pengetahuan Praktis Ragam Pneyakit Mematikan Yang Paling Sering Menyerang Kita. Jogjakarta: Buku Biru

Apriyanti, M ( 2012 ). 10 Tanaman Obat Paling Berkhaasiat \& Paling Di Cari, Jakarta : Pustaka Baru Press.

Arjadi Et Al. (2010). Regenerasi sel Pulau Langerhans pada Diabetes Yang Diberikan Rebusan Mahkota Dewa (paleria Macrocap(scheff)Boerl). Jurnal Efek Anti Diabetes Rebusan Mahkota Dewa,2 (2):117-126.

Arikunto,Suarsini, 2006. Prosedur Penelitian Suatu Pendekatan Prakktek : Edisi Revisi VI, Jakarta : PT Rineka Cipta.

Arisman, 2011. Diabetes Mellitus : Dalam Buku Ajar Ilmu Gizi Obesitas dan Diabetus Mellitus dan Dislipidemia, Jakarta: EGC.

Aziz, A. H., 2007. Metode Penelitian Keperawatan dan Teknik Analisa Data. Jakarta: Salemba Medika.

Corwin, E. J., 2009. Buku Saku Patofisiologi Corwin. s.l.: EGC

Dahlan, M. 2011. Statistika untuk Kedokteran dan Kesehatan. Jakarta: Salemba Medika.

Dahlan, M. S. 2014. Besar Sampel dalam Penelitian Kedokteran dan Kesehatan, Jakarta: Epidemiologi Indonesia.

Dharma, Kelana Kusuma.(2011). Metodologi Penelitian

Keperawatan. Jakarta: Penerbit Trans Info Media.
Dorland, W. 2014. Kamus Saku Kedokteran Dorland, Jakarta: EGC

Edward, Zzukarnain \& Yerizal Eti. 2016. Efek Ekstrak Buah Mahkota Dewa (Phaleria Machropa Scheff Boerl) Terhadap Kadar Malondialdehid Serum Pada Diabetes Mellitus Akibat Induksi Aloksan. Padang: Universitas Andalas.

Guyton, A. 2007. Buku Ajar Fisiologi Kedokteran, Jakarta: EGC

Husaini Usman, R. Purnomo Setiady Akbar, 2006. Pengantar Statistika, Edisi Kedua, Jakarta : PT. Bumi Aksara.

Kurniasih,(2015). Budidaya Mahkota Dewa, cara Olahan dan Khasiat Untuk Kesehatan. Penerbit Pustaka Baru Press. Yogyakarta. 